\title{
RESIDÊNCIA PEDAGÓGICA E SUAS PERSPECTIVAS NA EDUCAÇÃO DO CAMPO
}

\author{
Pedagogical Residence and its perspectives and field education \\ Residencia Pedagógica y sus perspectivas en la educación del campo
}

Aparecida de Jesus Soares Pereira*1, Vera Lúcia dos Santos Almeida Ribeiro ${ }^{1}$, Irany Paiva Moreira Teixeira Silva ${ }^{1}$, Miguel Ferreira Costa ${ }^{1,}$ Lucivânio Alves Borges $^{1}$

${ }^{1}$ Laboratório de Educação Musical, Curso de Licenciatura em Educação do Campo, Universidade Federal do Tocantins-UFT, Arraias-TO, Brasil.

*Correspondência: Curso de Licenciatura em Educação do Campo, Universidade Federal do Tocantins - UFT, Campus Professor Dr. Sérgio Jacintho Leonor, Av. Juraíldes de Sena e Abreu, Setor Buritizinho/ sala 10 - Bloco Bala, Arraias - Tocantins, Brasil.CEP:77.330-000.e-mail: cida.soares@uft.edu.br

\section{Artigo recebido em 03/04/2020 aprovado em 09/04/2020 publicado em 17/04/2020.}

\section{INTRODUÇÃO}

A implantação dos Cursos de Licenciatura em Educação do Campo no Brasil veio por meio de lutas do homem e da mulher do campo em busca de um ensino de qualidade que considere a sua realidade social, cultural, econômica e política. Sendo assim Rocha (2011) afirma que foram vários desafios que os movimentos sociais enfrentaram para se chegar à implantação das Licenciaturas em Educação do Campo, iniciadas pelos cursos de Pedagogia da Terra, tendo como objetivo a formação de docentes para as escolas do campo.

Sendo assim, o PRP (Programa Residência Pedagógica) foi implantado em 2018 na Universidade Federal do Tocantins (UFT)/ Campus Arraias, localizada na região sudeste do Tocantins, em parceria com o Curso de Licenciatura em Educação do Campo habilitação Artes Visuais e Música.

Neste sentido, o PRP proporciona ao discente de Licenciatura em Educação do Campo Artes Visuais e Música/Arraias -TO transmitir o seu conhecimento para as escolas campo, juntamente com o Estágio Curricular Supervisionado, possibilitando a articulação entre a teoria e a prática.
Neste sentido, o PRP procura cumprir com o seu papel de acordo com a Lei 11.769/08 que torna o ensino de música obrigatório nas escolas de educação básica (BRASIL, 2008), não restrito ao item curricular, mas como uma das linguagens artísticas constantes no ensino de Artes, de acordo com a LDB 9394/96.

Para tanto, o Curso de Educação do Campo tem como objetivo formar profissionais, que tenham domínio dos conteúdos e a clareza crítica daquilo que ensina e faz. O PRP em consonância com o estágio possibilita aos seus residentes a experiência necessária para atuar no ensino de artes/música tornando-o um profissional capacitado, consciente, crítico e reflexivo naquilo que propõe ensinar.

\section{METODOLOGIAS E MATERIAIS}

Foi utilizada a pesquisa bibliográfica com abordagem qualitativa, definida como um tipo de investigação voltada para os aspectos qualitativos de uma determinada questão, isto é, que considera a parte subjetiva de um problema ou situação. Para fundamentar este estudo foram utilizados autores que abordam sobre o papel da educação musical como: Amui; Guimarães (2016), PPC do Curso de Educação 
do Campo - Arraias-TO (2013), Romanelli (2016), nesta perspectiva Lakatos; Marconi (2003) discorrem sobre o tema de pesquisa.

\section{RESULTADOS E DISCUSSÃO}

Por meio do Curso de Educação do Campo e do PRP foram desenvolvidos vários trabalhos envolvendo os acadêmicos, preceptoras e alunos da escola campo, a Escola Estadual Girassol de Tempo Integral David Aires França (EEGTIDAF), em prol do bom desenvolvimento da música no contexto escolar.

Vale salientar que os integrantes do PRP Arraias - TO realizaram estágio de música na unidade escolar (EEGTIDAF), no ensino fundamental na séries finais e no Ensino Médio. Neste sentido, foi uma experiência ímpar, na qual os residentes puderam transmitir aos alunos da escola campo o que haviam aprendido na academia.

Segundo a BNCC, o Ensino Fundamental das séries finais e Ensino Médio são indispensáveis às interações e manifestações artísticas e culturais, nacional e internacionalmente, em diferentes circunstâncias podendo ocupar diversos espaços da escola.

Segundo Pimenta e Lima (2010), estágio apresenta uma das etapas mais importantes na formação do discente em licenciatura, no qual cumpre as exigências da Lei de Diretrizes e Bases da Educação Nacional (LDBEN) $n^{\circ}$ 9394/96. Neste sentido, essa formação constitui um campo especifico de intervenção profissional e prática social.

A Lei $n^{\circ} 11.788$ de 25 de setembro de 2008 define que:

Estágio é o ato educativo escolar supervisionado, desenvolvido no ambiente de trabalho, que visa à preparação para o trabalho produtivo de educandos que estejam frequentando o ensino regular em instituições de educação especial e dos anos finais do ensino fundamental, na modalidade de profissional da educação de jovens e adultos (BRASIL, 2008).
Neste sentido, o estágio em música proporciona ao discente de Licenciatura em Educação do Campo Artes e Música/Arraias -TO transmitir o seu conhecimento por meio do estágio possibilitando a articulação entre a teoria e a prática.

Sendo assim, a música apresenta várias particularidades, pois por meio da mesma percebe-se a melhoria da coordenação motora, sentido de pulsação, oralidade e lógico-matemático. Para tanto, a música tem por objetivo no âmbito escolar acrescentar e facilitar o aprendizado do educando, pois instiga o indivíduo a ouvir de maneira reflexiva. Assim, a educação musical deve ser vista como um processo comum, permanente, progressiva e refletiva (PPC, 2013, p. 33-34).

Em cumprimento a esta proposta, o PRP e a UFT promovem eventos consecutivos nos quais os discentes, docentes e preceptoras participam ativamente primando pela formação de qualidade, seja no âmbito da UFT ou da escola campo. Sendo assim, a BNCC (2016) destaca o item curricular Artes e em especial no que se menciona as orientações à Educação Musical.

\section{CONCLUSÃO}

Pode-se afirmar que por meio da música, inúmeras áreas de conhecimento podem ser estimuladas. Sendo assim, o PRP e o Curso de Educação do Campo tem trabalhado em conjunto para que o ensino da música nas escolas possa ser firmado conforme as leis mencionadas e as diretrizes da BNCC.

Porém a realidade que se encontra nas escolas é um ensino da música desenvolvido de forma superficial, por meio de imitações e repetições. Diante disto, o PRP e o Curso de Educação do Campo desenvolvem trabalhos nesta área. As aulas ministradas no curso enfatizam a essência do que é ensinar música. 


\section{AGRADECIMENTOS}

Primeiramente a Deus, por nos conceder saúde e força para prosseguirmos, pois sem Ele, nós não teríamos percorrido todo esse caminho. À CAPES pelo incentivo financeiro. À UFT por tornar possível a realização do PRP. Ao Curso de Educação do Campo pela oportunidade de aprimorar nossas experiências didático-pedagógicas e à Escola pela parceria.

Todos os autores declararam não haver qualquer potencial conflito de interesses referente a este artigo.

\section{REFERÊNCIAS}

AMUI, Gustavo Araújo; GUIMARÃES, Fernanda Albernaz do Nascimento (2016). Música na educação básica: referenciais teóricos de periódicos nacionais publicados entre 2000 e 2010. Per Musi. Ed. por Fausto Borém, Eduardo Rosse e Débora Borburema. Belo Horizonte: UFMG, n.34, p.89-112.

Base nacional comum curricular.

BRASIL. Lei $\mathbf{n}^{\mathbf{0}} \mathbf{1 1 . 7 6 9}$, de 18 de agosto de 2008. Altera a Lei $n^{\circ}$ 9.394, de 20 de dezembro de 1996, Lei de Diretrizes e Bases da Educação, para dispor sobre a obrigatoriedade do ensino da música na educação básica. Disponível em: http://www.planalto.gov.br/ccivil_03/_Ato20072010/2008/Lei/L11769.htm. Acesso em 15 de novembro de 2019.
BRASIL. Lei $\mathrm{n}^{\circ} 11.788$ de 25 de setembro de 2008. Dispõe sobre o estágio de estudantes. Disponível em: http://www.planalto.gov.br/ccivil_03/_ato20072010/2008/lei/111788.htm. Acesso em 16/11/2019.

BRASIL. Lei de Diretrizes e Bases da Educação nacional. $14^{\circ}$ edição, 2017.

LAKATOS, Eva Maria; MARCONI, Mariana de Andrade. Fundamentos de metodologia científica. 5. ed. São Paulo: Atlas, 2003.

PIMENTA, Selma Garrido; LIMA, Maria Socorro Lucena; Estágio e Docência. São Paulo; Cortez. 2010.

ROCHA, Maria Isabel Antunes; MARTINS, Aracy Alves(organizadores). Educação do Campo: desafios para formação de professores. 2. Ed. Belo Horizonte: Autentica Editora, 2011. (Coleção Caminhos da Educação do Campo: 1.

ROMANELLI, Guilherme Gabriel Ballande. Falando sobre a arte na base nacional comum curricular BNCC - um ponto de vista da educação musical. Linguagens - Revista de Letras, Artes e Comunicação. ISSN 1981-9943 Blumenau, v. 10, n. 3, p. 476-490, set./dez. 2016.

UFT - UNIVERSIDADE FEDERAL DO TOCANTINS. Projeto Político Pedagógico do Curso (PPC) de licenciatura em Educação do Campo: Códigos e Linguagens - Artes e Música, 2013. 